\title{
The development and validation of a scale measuring teacher autonomous behaviour
}

Citation for published version (APA):

Evers, A., Verboon, P., \& Klaeijsen, A. (2017). The development and validation of a scale measuring teacher autonomous behaviour. British Educational Research Journal, 43(4), 805-821. https://doi.org/10.1002/berj.3291

DOI:

10.1002/berj.3291

Document status and date:

Published: 01/08/2017

Document Version:

Peer reviewed version

Please check the document version of this publication:

- A submitted manuscript is the version of the article upon submission and before peer-review. There can be important differences between the submitted version and the official published version of record. People interested in the research are advised to contact the author for the final version of the publication, or visit the DOI to the publisher's website.

- The final author version and the galley proof are versions of the publication after peer review.

- The final published version features the final layout of the paper including the volume, issue and page numbers.

Link to publication

\section{General rights}

Copyright and moral rights for the publications made accessible in the public portal are retained by the authors and/or other copyright owners and it is a condition of accessing publications that users recognise and abide by the legal requirements associated with these rights.

- Users may download and print one copy of any publication from the public portal for the purpose of private study or research.

- You may not further distribute the material or use it for any profit-making activity or commercial gain

- You may freely distribute the URL identifying the publication in the public portal.

If the publication is distributed under the terms of Article 25fa of the Dutch Copyright Act, indicated by the "Taverne" license above, please follow below link for the End User Agreement:

https://www.ou.nl/taverne-agreement

Take down policy

If you believe that this document breaches copyright please contact us at:

pure-support@ou.nl

providing details and we will investigate your claim.

Downloaded from https://research.ou.nl/ on date: 26 Apr. 2023 
Title: The development and validation of a scale measuring teacher

$$
\text { autonomous behaviour }{ }^{1}
$$

\section{Arnoud T. Evers}

Open University of the Netherlands, Welten Institute, Faculty of Psychology and Educational Science, Research Centre for Learning, Teaching and Technology

arnoud.evers@ou.nl

\section{Peter Verboon}

Open University of the Netherlands, Faculty of Psychology and Educational Science,

Department of Methodology and Statistics

peter.verboon@ou.nl

\section{Andrea Klaeijsen}

Expertise Centrum Beroepsonderwijs (ECBO)

andrea.klaeijsen@ecbo.nl

Future correspondence (corresponding author):

Arnoud T. Evers

Open University of the Netherlands

Valkenburgerweg 177

6401 DL Heerlen

Telephone number: +31-(0)45-5762925

Fax number: +31-(0)45-5762782

E-mail address: arnoud.evers@ou.nl

${ }^{1}$ See for the article as published online: doi:10.1002/berj.3291. Please refer to this article as: Evers, A. T., Verboon, P., \& Klaeijsen, A. (2017). The development and validation of a scale measuring teacher autonomous behaviour. British Educational Research Journal 43(4), 805-821. 


\title{
Title: The development and validation of a scale measuring teacher autonomous behaviour
}

\begin{abstract}
In the current study a multi-dimensional scale that measures teacher autonomous behaviour is presented. The scale is applicable across the following educational sectors: primary education, secondary education, and vocational education. Based on an elaborate literature study, four theoretically relevant dimensions of teacher autonomous behaviour were derived. Psychometric characteristics of the instrument ${ }^{2}$ were tested among a sample of Dutch teachers working in primary, secondary, and vocational education $(\mathrm{N}=1111)$. Validity of our instrument was tested in several ways. First, by performing Confirmatory Factor Analysis, we tested the factorial structure, which confirmed the hypothesized four dimensions: 1) Primary work processes in the class, 2) Curriculum implementation, 3) Participation in decision making at school, and 4) Professional development. Thereafter, we calculated the scale's reliability, which appeared to be excellent. In addition, we tested for measurement invariance by cross-validating the study in the educational sectors mentioned above. Also, the convergent, divergent, and predictive validity was investigated. Teacher Autonomy appeared to predict workplace learning, more specifically experimenting, reflecting and school development. Finally, we investigated whether transformational leadership can facilitate teacher autonomy, which appeared to be the case. The results empirically confirm the four dimensions of teacher autonomous behaviour, which we derived from theory, and offer solid proof of the psychometric properties of our instrument. The instrument can be used by school leaders and policy makers to monitor autonomous
\end{abstract}

\footnotetext{
${ }^{2}$ The terms scale and instrument are used interchangeably in this article.
} 
behaviour. More generally, the development and use of this instrument helps us understand teacher autonomous behaviour and teacher professionalism.

Keywords: Teacher Autonomous Behaviour; Validation Study; Confirmatory Factor Analysis; Cross-validation

\section{Introduction}

Autonomy has always been a crucial element in any profession, especially in frontline professions where individual discretion is necessary to make the right decisions. Similarly, within the teaching profession, autonomy is a prevalent topic in debates about the teaching profession. Some authors, for example Hargreaves (2000), explain how the teachers' range and discretion regarding classroom judgement is diminished. He even talks about deprofessionalization of the teaching job. For a long time already, there has been a visible trend towards the "Audit Society" (Power, 1997), in which non-profit organisations and professionals in the non-profit sector are held 'accountable' for their performance. In the non-profit sector, we have seen increasing pressure from society to show that tax money is spent wisely and effectively. In the teaching profession, we have also seen a trend towards more accountability and performance management systems which, if not implemented in the right way, may constrain teachers' autonomy (Clegg, 2008; Helgøy \& Homme, 2007; Hodkinson \& Hodkinson, 2003). In the scientific field, we have also seen an increasing interest in teacher autonomy, which is considered to be a relatively new and multi-faceted concept (Yu-hong \& Ting, 2012). Yet the newness of the concept means that additional empirical research is required to improve theoretical understanding of teacher autonomy (Parker, 2015). 
Additionally, because autonomy of teachers is so crucial to making the right decisions at work and for the professional development of teachers (Lee, 2008), an important goal of this study is to develop a valid instrument for measuring teacher autonomous behaviour and for monitoring this behaviour. The validation process of the instrument is described in several stages (see 2. Method and 3. Results). The instrument can be used by school leaders and policy makers to make an inventory of the levels of teacher autonomous behaviour present in their schools. Based on these results, specific actions (e.g. with respect to leadership style as explained further on in this article) can be taken if, for example, the level is too low. Consequently, the instrument can be used to monitor actions that follow. In the next subsections, the theoretical meaning of teacher autonomy and the dimensions of teacher autonomous behaviour are elaborated upon.

\subsection{Teacher autonomy}

The term autonomy is derived from the Greek word "autonomia" (Castle, 2006), which is the state of living according to one's own laws rather than under the control of others (Haworth, 1986). In the educational domain, the interpretation of professional autonomy varies from autonomy as self-government at work to agency within a profession (Castle, 2006). In our article, teacher autonomy is defined as the freedom to act as a professional; that is the discretionary freedom to organise one's job (Benson, 2010; Runhaar et al., 2013; Webb, 2002). This is different from the much broader concept of agency, which means the experience of control over the choices one makes in work and how these choices are based on personal goals, interests and personal motives (Vähäsantanen et al., 2008). Teacher autonomy, as defined in our article, also differs from organisational autonomy (Yu-hong \& Ting, 2012). Schools in the Netherlands for example have been granted more organisational 
autonomy from the government for making financial and strategic decisions (Karsten \& Meijer, 1999). This does not mean teachers have also been given more autonomy in their work (Hargreaves, 2000). The question here is whether school leaders are in the position and have trust - in their own capacities and in their teachers - - to create the conditions for teachers to act autonomously in their jobs.

Teacher autonomy is essential for numerous reasons. First of all, individual teacher autonomy contributes to teacher status legitimated at the collective, societal level (Helgøy \& Homme, 2007). In addition, teacher autonomy in the classroom is strongly connected to the decision of teachers to stay in the teaching profession (Webb et al., 2004). Finally, perceived autonomy by teachers plays a positive role when it comes to their professional development (Kleinhenz \& Ingvarson, 2004; Lee, 2008).

\subsection{Dimensions of teacher autonomous behaviour}

In the previous section, we defined teacher autonomy in general as the freedom to act as a professional and to organize one's job. Because it is a relatively new and multifaceted concept, it is theoretically important to describe it more concretely. Based on a literature study, we defined it as the influence of teachers to organise their work activities, which can be classified into four categories: 1) Primary work processes in the class, 2) Curriculum implementation, 3) Participation in decision making at school, and 4) Professional development. This classification is based on an examination of literature appearing inpeerreviewed journals about teacher autonomy, using the search terms: 'teacher autonomy', 'teacher control' and 'teachers taking responsibility'. The search was limited to literature published between 1990 and 2016. The following search engines were used: Science Direct, 
PiCarta, Google Scholar and EBSCO host. The accompanying references are depicted in Table 1.

$* * * * * * * * * * * * * * * * * * * * * * * * * * *$ Insert Table 1 about here

Some references belong in more than one category. For example, Pearson and Moomaw $(2005,2006)$, define teacher autonomy as being composed of two dimensions: general teaching autonomy (in the class) and curricular autonomy. As can be seen from Table 1, most literature focusses on teacher autonomy with regard to primary work processes in the class.

The definition and categories we have derived from the literature are behavioural in nature. Although some articles define teacher autonomy as a feeling, attitude or belief (e.g. Crawford, 2001), most articles (and also the articles we use for the item generation, see below) focus on the behavioural dimension; that is as teachers creating their own working conditions.

The dimensions are defined here in more detail. 1) Primary work processes in the class deals with issues concerning classroom standards of conduct and personal on-the-job discretion (e.g. Pearson \& Moomaw, 2005, 2006). 2) Curricular autonomy deals with issues concerning selection of activities and materials and instructional planning and sequencing (Benson, 2010; Mustafa \& Cullingford, 2008; Pearson \& Moomaw, 2005, 2006). 3) Participation in decision making at school, is defined as teachers' power in decision-making regarding the regulation of working conditions and the school environment (e.g. Öztürk, 2012; Pugh \& Zhao, 2003). Finally, 4) Professional development, can be described as teachers' control over professional development activities (Powell \& McGowan, 1996; Webb, 2002). These 
dimensions reflect a broad perspective on the work practices of teachers, in line with what Hoyle (1975), and later for example Jongmans et al. (2014), called an extended professional orientation. We will come back to this notion in the Discussion section of this article.

\subsection{Teacher autonomous behaviour: theoretical foundation of convergent, divergent and predictive validity}

In order to determine the construct validity of the teacher autonomous behaviour instrument, the relationships of the teacher autonomous behaviour scale with other variables in the nomological network were studied. First of all, convergent validity is proven when a measurement instrument shows positive and high associations with a measurement instrument that intends to investigate theoretically similar concepts. A theoretically similar concept we used for this purpose is perceived autonomy satisfaction, as described in the Basic Psychological Needs Theory (Chen et al., 2015; Deci \& Ryan, 2000; Ryan \& Deci, 2000). This is defined as the extent to which teachers experience a sense of desire and willingness, rather than feelings of external control (Chen et al., 2015). In order to test convergent validity, we therefore correlated the four dimensions of teacher autonomous behaviour with perceived autonomy satisfaction.

To establish divergent validity one needs to prove low associations with a construct that is theoretically unrelated or at least weakly related (Nunnally \& Bernstein, 1991). In our study we used bureaucracy (Skaalvik \& Skaalvik, 2010), defined as having, for example, a high amount of paper work and strict procedures, as a concept that is supposed to be weakly related to teacher autonomous behaviour. That is, one can still act freely and influence one's job, even under strict procedures and paperwork load. 
We tested the predictive validity of the teacher autonomous behaviour instrument by relating each dimension to professional development as measured by the dimensions experimenting, reflecting upon and asking for feedback, and collaborating with colleagues with the aim of improving school development (Evers et al., 2016). Research to date supports teacher autonomy as an essential condition for professional development (Kleinhenz \& Ingvarson, 2004; Lee, 2008; Poulson \& Avramidis, 2003).

Finally, it was investigated whether transformational leadership is an important condition to facilitate teacher autonomous behaviour. Previous studies found a significant relationship between these concepts in other professional occupations (Hammond et al., 2015; Hetland et al., 2011).

\section{Method}

\subsection{Survey design and item generation}

Apart from a comprehensive literature search into teacher autonomy, several current taxonomies (Kwakman, 2003; Pearson \& Moomaw, 2005, 2006) were used as input for the current survey. Based on the theoretical knowledge (see the previous section) we differentiated four dimensions of teacher autonomous behaviour. The survey items in each dimension were based on taxonomies of Kwakman (2003) and Pearson and Moomaw (2005, 2006). Table 2 shows the survey items and these sources. The items are translated from Dutch. We developed 8 items for the dimension 'primary work processes in the class', 6 items for the dimension 'curriculum implementation', 5 items for the dimension 'participation in decision making at school', and 5 items for the last dimension 'professional development'. Respondents answered all items on a seven-point rating scale ranging from 1 $=$ almost never, to $7=$ almost always. The items were introduced with the following 
sentences: "The following items are about autonomous behaviour. Please indicate to what extent the following statements apply to you."

\subsection{Face validity}

In order to check whether the items sufficiently covered the dimensions and whether items were understandable and well formulated, interviews were conducted with three teachers in primary education (all women, average age 41,3 years), three in secondary education (one women, two men, average age 31 years), and four in vocational education (three women, one man, average age 45,5). Two questions lead these interviews: 1) Do the items cover the dimensions?, and 2) Are all items formulated well and understandable? All teachers found that the items covered the dimensions and were satisfied with the items within each dimension. Items were also considered well-formulated, as teachers only offered minor remarks about item formulation, which were then incorporated in the questionnaire. For example, the item: "I have a say in the tasks that are assigned to me." was changed into "I have a say in the (educational) tasks that are assigned to me.", to stress the educational side of tasks.

\subsection{Participants and procedure}

The sample in this study consisted of 1111 Dutch teachers (493 teachers in primary education, 382 teachers in secondary education, and 207 teachers in vocational education, 29 working in multiple educational levels). Participants were invited for the survey via e-mail (via a unique hyperlink). In total, data collection took approximately two and a half weeks. After one week a reminder was sent. In order to increase the response, incentives were used (a lottery with gift coupons). The total response rate was $59.5 \%$. The current study was 
conducted by a certified company for online marketing research operating in the Netherlands. For age and gender the sample was representative for teachers in the Netherlands (based on statistics of the Ministry of Education in the Netherlands). Respondents' age was between 20 and 64 years for primary education $(M=43.7$ years; $S D=$ 11.6 years), between 21 and 65 years for secondary education $(M=46.6$ years; $S D=11.5$ years), and between 24 and 71 years for vocational education $(M=49.6$ years; $S D=10.9$ years). With respect to gender, in primary education $19.5 \%$ of the respondents were male, in secondary education $53.7 \%$ of the respondents were male, and in vocational education $52.7 \%$ of the respondents were male.

\subsection{Measures}

Several measures were used to calculate the convergent, divergent, and predictive validity of our teacher autonomous behaviour scale.

Perceived autonomy, the extent to which teachers experience a sense of volition and willingness, rather than feelings of external control of coercion, was measured with a scale from Chen et al. (2015). The scale was measured with four items, scored on a 7-point rating scale ranging from 1 (= not applicable at all), to 7 (= completely applicable). An example item was: "In my work I have a feeling of choice and freedom in the things I undertake". Cronbach's alpha was .89.

Bureaucracy was measured with a scale we developed based upon Skaalvik and Skaalvik (2010), consisting of eight items. These were also scored on a 7-point rating scale ranging from 1 (= completely disagree), to 7 ( completely agree). An example item was: "The time I spend on paperwork, I should spend on preparing the lessons". Cronbach's alpha was .90. 
Professional development was measured by three dimensions based upon Evers et al.

(2016): Experimenting, Reflecting and asking for feedback, and Collaborating with colleagues with the aim of improving school development. Experimenting consisted of five items, all measured on a 7-point rating scale ranging from 1 (= almost never) to 7 (= almost always). An example item was: "Trying out new teaching methods in my lesson". Cronbach's alpha was: .86. Reflecting and asking for feedback was measured with four items, all measured on a 7-point rating scale ranging from 1 (= almost never) to 7 (= almost always). An example item was: "Asking pupils for feedback on the way I teach". Cronbach's alpha was: .76. Collaborating with colleagues with the aim of improving school development was measured by four items, measured on a 7-point rating scale ranging from 1 (= almost never) to 7 (= almost always). An example item was: "Discussing ideas about educational improvement and innovation in my school with colleagues". Cronbach's alpha was .85 .

Transformational leadership (the dimension intellectual stimulation, based upon Geijsel et al. (2009) was assessed with 6 items, measured on a 7-point rating scale ranging from 1 (= almost never) to 7 (= almost always). An example item was: "Encourages teachers to try new things in line with their own interests". Cronbach's alpha was .95.

\section{Results}

\subsection{Exploratory and confirmatory factor analysis}

We started with exploratory factor analysis on the 24 items as described in Table 2 . The items "The selection of student-learning activities in my class is under my control." and "I select the teaching methods and strategies I use with my pupils/students." from the autonomous behaviour subscale 'primary work processes in the class' loaded unexpectedly 
on the autonomous behaviour subscale 'curriculum implementation'. Therefore, these were deleted from all further analyses.

We then fitted a four-factor model to examine the four-dimensional structure of teacher autonomous behaviour (TA) in a Confirmatory Factor Analysis (CFA). Based on the 22 items we obtained a $\chi^{2}$ of 2041 with 203 degrees of freedom, with the following fit values: $C F I=$ $.901, \mathrm{TLI}=.882$ and RMSEA $=.090$. Since these fit values are slightly lower than the values usually accepted to indicate good fit we studied the structure of the model in more detail. To improve the model two items were deleted from the scales. First, from the subscale ' autonomous behaviour in professional development" we deleted the first item (“I have a say on the planning of my professional development activities.") because it correlated very highly with the second item. Furthermore, in the subscale 'participation in decision making at school' an item was deleted ("I have a say about what does and does not belong to my task.") because it correlated highly with two other items of the scale. These model adaptions appeared to improve the model fit $(\mathrm{CFI}=.928, \mathrm{TLI}=.917$ and $\mathrm{RMSEA}=.078$, see Table 3$)$. These fit values are generally considered acceptable (Browne \& Cudeck, 1993; Hoyle, 1995), thus indicating that the model fits the data well.

We compared this four-dimensional model with the more parsimonious three, two, and one factor models (the factors correspond with the four dimensions in Table 1). In the threefactor model, the items concerning professional development and participation were assumed to load on a single factor. In the two-factor model, also the primary work process and participation items were assumed to load on a single factor. See Table 3 for the fit values of all four models. 
The four-factor model clearly fits the data best, thus supporting the idea that teacher autonomous behaviour is a four-dimensional construct.

\subsection{Reliabilities}

To determine the psychometric characteristics of a scale it is necessary to define its reliability. The internal consistencies of the teacher autonomous behaviour dimensions are shown in Table 4. The internal consistency of all the dimensions was very good, much higher than the recommended .70 .

\subsection{Cross-validation}

To examine the robustness of the model we tested the four-dimensional model with the same data separately for the three groups of educational level (primary, secondary, and vocational education). In each group the fit values were as shown in Table 5. All fit indices showed acceptable values; the values of secondary education were slightly lower than primary and vocational education.

\subsection{Construct validity}

Convergent and divergent validity are the two types of validity that together make up construct validity. Convergent validity refers to the degree to which two scales that theoretically should be related are in fact related. Divergent validity, on the other hand, examines whether scales that are supposed to be unrelated are, in fact, unrelated or at least weakly related. Table 6 shows all the descriptives, correlations between variables, and their reliabilities. 


\subsubsection{Convergent validity}

We used the 'perceived autonomy' (PA) scale to test the convergent validity of the autonomous behaviour subscales. We expected that teacher autonomous behaviour (TA) is moderately to highly related to the PA. The teacher autonomous behaviour subscales correlate with PA as follows:

The correlations are all statistically significant $(p<.05)$ and the relationship is moderate.

\subsubsection{Divergent validity}

We used the 'bureaucracy' (BC) scale to test the divergent validity of the TA subscales. We expected that TA is only weakly related to BC (negative relationship). The TA subscales correlate with $\mathrm{BC}$ as follows:

* Insert Table 8 about here

Although the correlations are all statistically significant, the relationships are weakly negative with $\mathrm{BC}$.

\subsection{Predictive validity}

We used three subscales ('experimenting', 'reflecting and asking feedback', 'collaborating school development') from the construct 'professional development' (PD) to test the 
predictive validity of the TA subscales. We expected all PD subscales to be predicted by the TA subscales. The TA subscales correlate with PD as follows:

The correlations are all statistically significant and the relationship is weak to moderate. Regressing 'experimenting' on the TA subscales yielded two statistically significant regression coefficients: 'curriculum implementation' ( $b=.199, \mathrm{SE}=.036, t=5.56, p=.000)$ and 'participation' ( $b=.152, \mathrm{SE}=.040, t=3.62, p=.000)$. The other subscale's appeared not significant. The multiple correlation of the four subscales is $R=.329$, indicating that about $11 \%$ of the variance in experimenting can be explained by the TA subscales. Regressing 'reflecting and asking for feedback' on the TA subscales yielded one statistical significant regression coefficient: 'curriculum implementation' ( $b=.187, \mathrm{SE}=.035, t=5.28, p$ $=.000)$. The other subscale's appeared not to be significant. The multiple correlation of the four subscales is $R=.305$, indicating that about $9 \%$ of the variance in 'reflecting and asking for feedback' can be explained by the TA subscales.

Regressing 'collaborating school development' on the TA subscales again yielded two statistically significant regression coefficients: 'curriculum implementation' ( $b=-.119, \mathrm{SE}=$ $.038, t=3.14, p=.002)$ and 'participation' $(b=.488, \mathrm{SE}=.042, t=11.49, p=.000)$. The other subscales were not significant. The multiple correlation of the four subscales is $R=.428$, indicating that about $18 \%$ of the variance in 'collaborating school development' can be explained by the TA subscales. 


\subsection{Facilitating teacher autonomous behaviour by transformational leadership}

The relation between 'transformational leadership' (TL) and the four dimensions of teacher autonomous behaviour was tested with a multivariate linear model (Pillai's trace $=.209, F=$ 73.17, $d f=4,1106, p=.000)$. The univariate results are given in the Table 10. As the Table shows, 'transformational leadership' predicted all four dimensions of teacher autonomous behaviour.

\section{Discussion}

The main purpose of this study was to theoretically develop and validate a multidimensional instrument that can be used in different educational settings to measure teacher autonomous behaviour. This study is not the first attempt to grasp teacher autonomy and to develop a sound instrument that enables measuring this important aspect of the teaching profession. Friedman (1999), for example, presented a scale to measure teachers' sense of work autonomy. Although his scale shows some similarities with our instrument, our effort is more strongly built on an extensive literature review, a larger sample, and on advanced statistical analyses. In addition, and in contrast with Friedman, in order to validate the teacher autonomy scale we not only included primary and secondary education teachers in our sample, but also vocational education teachers.

The instrument described in this study captures four relevant dimensions of teacher autonomous behaviour, which were derived from the literature. These dimensions include 'primary work processes in the class', 'curriculum implementation', 'participation in decision making at school', and 'professional development'. Accordingly, these reflect a broad perspective on the individual practice of teachers both within and outside the classroom, 
and can be perceived in the context of extended professionality (as introduced in 1975 by Hoyle, more recently also for example in Hoyle \& John, 1995 and Jongmans et al., 2014). This entails an extended view on the teaching profession, characterized by a perspective on teaching that embraces the broader context of education and school policy. It is important for teachers to be involved in curriculum development and other decisions in schools, instead of simply implementing what others have come up with, as Stenhouse (1988) already concluded. Several qualitative case studies have indicated how implementing what policy prescribes can potentially hinder teachers in their work. For example, Mustafa and Cullingford (2008) found that obliging teachers to stick to the textbook hinders teachers in varying their teaching methods. Similarly, Helgøy and Homme (2007) concluded that prescribing detailed curriculuminstructions limitsteachers' individual freedom in their teaching. Instead, flexible application of regulation in schools is necessary (Öztürk, 2012). As such, this study builds on the notion that teacher autonomy is an important aspect of teachers' professional behaviour. Teachers are not solely dependent on policy makers, educational scientist, and managers. As a professional group, by making use of collaborative and reflective practices they can be viewed as key professionals themselves (Evers et al., 2016; Stenhouse, 1988). In exercising their autonomy they are able to function as high quality professionals. This study provides a validated scale to measure teachers' autonomy. As a result, the development and use of this instrument adds to our understanding of teacher professionalism.

In the following section the findings regarding the validity of the teacher autonomous behaviour scale are discussed. 


\subsection{Factorial validity, reliabilities, and cross-validation}

The dimensionality of the teacher autonomous behaviour scale was examined by means of a confirmatory factor analyses (CFA) to find confirmation for the hypothesized four-factor structure. In addition, three alternative measurement models were analysed and compared. Based on these analyses the four-factor structure clearly showed the best fit. In other words, the results of the CFA supported the dimensions derived from the literature review. Reliability analyses showed that the internal consistency of each of the four scales proved to be very good. In order to verify whether the dimensionality of the scale holds among different samples, a cross-validation analysis was performed. This cross-validation showed that the proposed four-factor model holds among different samples of teachers (primary, secondary, and vocational).

\subsection{Construct validity: convergent and divergent validity}

Convergent validity of the teacher autonomy scale was tested by correlating each of its subscales with the 'perceived autonomy' scale (Chen et al., 2015), a theoretically similar concept as described in the Basic Psychological Needs Theory (Chen et al., 2015; Deci \& Ryan, 2000; Ryan \& Deci, 2000). The convergent validity was established as the correlations between this 'perceived autonomy' scale and the four sub-scales were all significant and moderate. The divergent validity of the scale appeared to be good as well. Divergent validity refers to the extent to which two measurements that are expected to be unrelated appear in fact to be unrelated (Nunnally \& Bernstein, 1991). The scale for 'bureaucracy' (based on Skaalvik \& Skaalvik, 2010) was used to test the divergent validity of the teacher autonomous behaviour subscales. Results showed that the correlations between 'bureaucracy', on the one hand, and each of the subscales, on the other, were significant and weakly negative, indicating that 
the 'bureaucracy' scale and each of the four subscales of our instrument measure different constructs.

\subsection{Predictive validity}

To test the predictive validity of the teacher autonomous behaviour subscales, we used three subscales ('experimenting', 'reflecting and asking feedback', c'ollaborating school development') from the construct 'professional development' (PD) as dependent variables (see Evers et al., 2016). We hypothesized that the teacher autonomous behaviour (TA) subscales would predict all PD subscales, as previous research suggests (Kleinhenz \& Ingvarson, 2004; Lee, 2008; Poulson \& Avramidis, 2003). The TA subscales 'curriculum implementation' and 'participation' both predicted 'experimenting'. 'curriculum implementation' appeared to predict 'reflecting and asking for feedback'. Finally, 'curriculum implementation' and 'participation in decision making at school' predicted 'collaborating with colleagues with the aim of improving school development'. We must also conclude that, although weak to moderate correlations between the other TA subscales ('primary work processes in the class' and 'autonomy in professional development') and the PD subscales were found, these TA subscales did not have enough power to explain PD. This indicates that especially TA in 'curriculum implementation' and 'participation in decision making at school' is vital for PD.

\subsection{Transformational leadership facilitates teacher autonomous behaviour}

An interesting question remains: how can one facilitate teacher autonomous behaviour? Transformational leadership has been found to be an important condition for autonomy of employees in other professional occupations (Hammond et al., 2015; Hetland et al., 2011). Therefore, we tested the extent that transformational leadership facilitates all four 
dimensions of teacher autonomous behaviour. Results showed that transformational leadership (more specifically the dimension intellectual stimulation) has the potential to facilitate all four dimensions, especially autonomous behaviour in 'participation in decision making at school' and 'professional development'. This means that in order to facilitate teacher autonomy, school leaders should "encourage teachers to question their own assumptions, beliefs, and values and enhance teachers' ability to solve individual, group, and organisational problems" (Geijsel et al., 2009, p. 411).

\subsection{Limitations and Recommendations for Future Research}

Some limitations of the study need to be addressed. First, the study is based on a large sample of teachers working in different contexts and in different educational levels. Independent samples or datasets were not used, which is typically done in cross-validation analysis. It is recommended that future studies aiming to test our instrument use more than one sample, and that these samples are collected independently. Second, a bias can be present due to self-reports of respondents. To mitigate this, it is essential to guarantee anonymity when using this instrument, as we did in our study. Third, this study was crosssectional in nature. Further research, using repeated measures, is needed in order to allow calculations of test-retest reliability. A fourth limitation is that the instrument is developed and validated within a Dutch context. Although the literature used to theoretically develop the instrument and the other scales used in this study are derived from international literature, research in other countries is recommended to further establish the reliability and validity of this instrument in other contexts.

In addition to opening avenues for quantitative research, this instrument for teacher autonomous behaviour can also be useful for future research involving qualitative policy 
case studies, similar to the ones mentioned above (that is Helgøy \& Homme, 2007; Mustafa \& Cullingford, 2008). Case studies can add to our understanding of the complex interrelationships between teacher autonomy and other factors. The instrument can track teachers' autonomous behaviour both within and outside the classroom, and can help explain how policy initiatives may influence this behaviour. To conclude, in this article we developed an instrument for teachers' autonomous behaviour, which proved to be valid, and we believe is therefore useful in future quantitative and qualitative studies on this pertinent and prevalent topic.

\section{References}

Ballou, D. \& Podgursky, M. (1995) Education Policy and Teacher Effort, Industrial Relations, 34(1), 21-39. doi:10.1111/j.1468-232X.1995.tb00358.x

Benson, P. (2010) Teacher education and teacher autonomy: Creating spaces for experimentation in secondary school English language teaching, Language Teaching Research, 14(3). doi:10.1177/1362168810365236

Browne, M.W. \& Cudeck, R. (1993) Alternative ways of assessing model fit, in: K. A. Bollen \& J. S., Long (Eds) Testing Structural Equation Models (Beverly Hills, CA, Sage), 136-162.

Castle, K. (2006) Autonomy through pedagogical research, Teaching and Teacher Education, 22(8), 1094-1103. doi:10.1016/j.tate.2006.07.001

Chen, B., Vansteenkiste, M., Beyers, W., Boone, L., Deci, E.L., Van der Kaap-Deeder, J. \& Verstuyf, J. (2015) Basic psychological need satisfaction, need frustration, and need strength across four cultures, Motivation and Emotion, 39(2), 216-236. 
doi:10.1007/s11031-014-9450-1.

Clegg, S. (2008) Academic identities under threat?, British Educational Research Journal, 34(3), 329-345. doi:10.1080/01411920701532269

Crawford, J.R. (2001) Teacher autonomy and accountability in charter schools, Education and Urban Society, 33(2), 186-200.

Deci, E.L. \& Ryan, R.M. (2000) The "What" and "Why" of Goal Pursuits: Human Needs and the Self-Determination of Behavior, Psychological Inquiry, 11(4), 227-268. doi:10.1207/S15327965PLI1104_01

Dee, J., Henkin, A. \& Pell, S. (2002) Support for innovation in site-based-managed schools: Developing a climate for change, Educational Research Quarterly, 25(4), 36-49.

Evers, A.T., Kreijns, K. \& Van der Heijden, B.I.J.M. (2016) The Design and Validation of an Instrument to Measure Teachers' Professional Development at Work, Studies in Continuing Education, 38(2), 162-178. doi: 10.1080/0158037X.2015.1055465.

Friedman, I.A. (1999) Teacher-perceived work autonomy: the concept and its measurement, Educational and Psychological Measurement, 59(1), 58-76. doi:10.1016/09249338(96)88411-2

Gawlik, M. (2007) Beyond the charter schoolhouse door: Teacher-perceived autonomy, Education and Urban Society, 39(4), 524-553.

Geijsel, F.P., Sleegers, P.J.C., Stoel, R.D. \& Krüger, M.L. (2009) The effect of teacher psychological and school organizational and leadership factors on teachers' professional learning in Dutch schools, The Elementary School Journal, 109(4), 406-427.

Hammond, M., Cleveland, J.N., O’Neill, J.W., Stawski, R.S. \& Jones Tate, A. (2015) Mediators 
of transformational leadership and the work-family relationship, Journal of Managerial Psychology, 30(4), 454-469. doi:10.1108/JMP-10-2011-0090

Hargreaves, A. (2000) Four ages of professionalism and professional learning, Teachers and Teaching: History and Practice, 6(2), 151-182.

Haworth, L. (1986) Autonomy (New Haven, Yale University Press).

Helgøy, I. \& Homme, A. (2007) Towards a new professionalism in school? A comparative study of teacher autonomy in Norway and Sweden, European Educational Research Journal, 6(3), 232-249. doi:10.2304/eerj.2007.6.3.232

Hetland, H., Hetland, J., Andreassen, C.S., Pallesen, S. \& Notelaers, G. (2011) Leadership and fulfillment of the three basic psychological needs at work, Career Development International, 16(5), 507-523. doi:10.1108/13620431111168903

Hodkinson, P. \& Hodkinson, H. (2003) Individuals, communities of practice and the policy context: school teachers' learning in their workplace, Studies in Continuing Education, 25(1), 3-21. doi:10.1080/01580370309284

Hoyle, E. (1975) Leadership and decision-making in education, in: M. Hughes (Ed.) Administering Education: International Challenge (London, The Athlone Press), 30-44.

Hoyle, E. \& John, P. D. (1995) Professional knowledge and professional practice (London, UK, Cassell).

Hoyle, R.H. (1995) Structural equation modelling: Concepts, issues, and applications (Thousand Oaks, CA, Sage).

Jongmans, C.T., Sleegers, P.J.C., Biemans, H.J.A. \& de Jong, F.P.C.M. (2004) Teachers' participation in school policy: Nature, extent and orientation. The Journal of Agricultural 
Education and Extension, 10(1), 1-12.

Jönsson, B. (2005) A case study of successful e-learning: A web-based distance course in medical physics held for school teachers of the upper secondary level, Medical Engineering \& Physics, 27, 571-581.

Karsten, S. \& Meijer, J. (1999) School-based management in the Netherlands: The educational consequences of lump-sum funding, Educational Policy, 13, 421-439.

Kleinhenz, E. \& Ingvarson, L. (2004) Teacher accountability in Australia: current policies and practices and their relation to the improvement of teaching and learning, Research Papers in Education, 19(1), 31-49. doi:10.1080/0267152032000176963

Kwakman, K. (2003) Factors affecting teachers' participation in professional learning activities, Teaching and Teacher Education, 19(2), 149-170. doi:10.1016/S0742051X(02)00101-4

Lee, I. (2008) Understanding teachers' written feedback practices in Hong Kong secondary classrooms, Journal of Second Language Writing, 17(2), 69-85. doi:10.1016/j.jslw.2007.10.001

Lu, J., Jiang, X., Yu, H. \& Li, D. (2015) Building collaborative structures for teachers' autonomy and self-efficacy: the mediating role of participative management and learning culture, School Effectiveness and School Improvement, 26(2), 240-257. doi:10.1080/09243453.2014.888086

Mustafa, M. \& Cullingford, C. (2008) Teacher autonomy and centralised control: The case of textbooks, International Journal of Educational Development, 28(1), 81-88. doi:10.1016/j.ijedudev.2007.07.003 
Nakata, Y. (2011) Teachers' readiness for promoting learner autonomy: A study of Japanese EFL high school teachers, Teaching and Teacher Education, 27(5), 900-910. doi:10.1016/j.tate.2011.03.001.

Nielsen, D. C., Barry, A. L. \& Staab, P. T. (2008) Teachers' reflections of professional change during a literacy-reform initiative, Teaching and Teacher Education, 24(5), 12881303.

Nunnally, J. \& Bernstein, I.H. (1991) Psychometric theory (New York, McGraw).

Oates, J.V. (2011) Teaching China in Scotland's secondary schools as Sino-Scottish engagement intensifies, Educational Review, 63(1), 53-64. doi:10.1080/00131911.2010.500053

Oberfield, Z.W. (2016) A Bargain Half Fulfilled: Teacher Autonomy and Accountability in Traditional Public Schools and Public Charter Schools, American Educational Research Journal, 53(2), 296-323. doi:10.3102/0002831216634843

Osei, G. \& Brock, C. (2006) Decentralisation in education, institutional culture and teacher autonomy in Ghana, Journal of Education Policy, 21(4), 437-458.

Ovando, M. \& Cavazos, M. (2004) Principals' Instructional Leadership in Successful Hispanic Majority High Schools, Scholar-Practitioner Quarterly, 2(3), 7-24.

Öztürk, i̇.H. (2012) Teacher 's Role and Autonomy in Instructional Planning : The Case of Secondary School History Teachers with regard to the Preparation and Implementation of Annual Instructional Plans, Educational Sciences: Theory \& Practice, 12(1), 295-299.

Parker, G. (2015) Teachers' autonomy, Research in Education, 93, 19-33.

Pearson, L. (1995) The prediction of teacher autonomy from a set of work-related and 
attitudinal variables, Journal of Research \& Development in Education, 28(2), 79-85.

Pearson, L. \& Hall, B. (1993) Initial construct validation of the teaching autonomy scale. The Journal of Educational Research, 86(3), 172-178.

Pearson, L. \& Moomaw, W. (2005) The Relationship between Teacher Autonomy and Stress, Work Satisfaction, Empowerment, and Professionalism, Educational Research Quarterly, 29(1), 38-54.

Pearson, L. \& Moomaw, W. (2006) Continuing validation of the teaching autonomy scale, The Journal of Educational Research, 100(1), 44-51.

Poulson, L. \& Avramidis, E. (2003) Teachers of Literacy, British Educational Research Journal, 29(4), 543-560. doi:10.1080/0141192032000099360

Powell, J. \& McGowan, T. (1996) In search of autonomy: Teachers' aspirations and expectations from a school-university collaborative, Teaching and Teacher Education, 12(3), 249-260.

Power, M. (1997) The audit society: Rituals of verification (Oxford, Oxford University Press).

Pugh, K.J. \& Zhao, Y. (2003) Stories of teacher alienation: a look at the unintended consequences of efforts to empower teachers, Teaching and Teacher Education, 19(2), 187-201. doi:10.1016/S0742-051X(02)00103-8

Runhaar, P., Konermann, J. \& Sanders, K. (2013) Teachers' organizational citizenship behaviour: Considering the roles of their work engagement, autonomy and leadermember exchange, Teaching and Teacher Education, 30, 99-108. doi:10.1016/j.tate.2012.10.008

Ryan, R.M. \& Deci, E.L. (2000) The Darker and Brighter Sides of Human Existence: Basic 
Psychological Needs as a Unifying Concept, Psychological Inquiry, 11(4), 319-338. doi:10.1207/S15327965PLI1104_03

Skaalvik, E. M. \& Skaalvik, S. (2010) Teacher self-efficacy and teacher burnout: A study of relations, Teaching and Teacher Education, 26(4), 1059-1069. doi:10.1016/j.tate.2009.11.001

Stenhouse, L. (1988) Artistry and teaching: The teacher as focus of research and development. Journal of Curriculum and Supervision, 4(1), 43-51.

Vähäsantanen, K., Hökkä, P., Eteläpelto, A., Rasku-Puttonen, H. \& Littleton, K. (2008) Teachers' professional identity negotiations in two different work organisations, Vocations and Learning, 1(2), 131-148.

Webb, P.T. (2002) Teacher power: the exercise of professional autonomy in an era of strict accountability. Teacher Development, 6(1), 47-62. doi:10.1080/13664530200200156

Webb, R., Vulliamy, G., Hämäläinen, S., Sarja, A., Kimonen, E. \& Nevalainen, R. (2004) Pressures, rewards and teacher retention: a comparative study of primary teaching in England and Finland, Scandinavian Journal of Educational Research, 48(2), 169-188. doi:10.1080/0031383042000198530

Wilson, S. (1993) The self-empowerment index: A measure of internally and externally expressed teacher autonomy, Educational and Psychological Measurement, 53(3), 727737.

Woolfolk, A.E. \& Hoy, W.K. (1990) Prospective teachers' sense of efficacy and beliefs about control, Journal of Educational Psychology, 82(1), 81-91. doi:10.1037//00220663.82.1.81 
Yu-hong, J. \& Ting, M. (2012) A review of the research on language teacher autonomy, SinoUS English Teaching, 9(4), 1045-1055. 


\section{Table 1}

Dimensions of Teacher Autonomous Behaviour

\begin{tabular}{l|l}
\hline Category & References \\
\hline Primary work processes in the class & (Ballou \& Podgursky, 1995; Crawford, 2001; \\
& Dee et al., 2002; Friedman, 1999; Helgøy \& \\
& Homme, 2007b; Jönsson, 2005; Karsten \& \\
& Meijer, 1999; Kleinhenz \& Ingvarson, 2004; \\
& Lu et al., 2015; Nakata, 2011; Nielsen et al. \\
& 2008; Oberfield, 2016; Pearson \& Hall, 1993; \\
& Pearson \& Moomaw, 2005, 2006; Pearson, \\
& 1995; Pugh \& Zhao, 2003; Runhaar et al., \\
& 2013; Woolfolk \& Hoy, 1990) \\
\hline Curriculum implementation & (Benson, 2010; Crawford, 2001; Friedman, \\
& 1999; Mustafa \& Cullingford, 2008; Oates, \\
& 2011; Osei \& Brock, 2006; Pearson \& Hall, \\
& 1993; Pearson \& Moomaw, 2005, 2006; \\
& Pearson, 1995) \\
\hline Participation in decision making at school & (Crawford, 2001; Friedman, 1999; Gawlik, \\
& 2007; Lu et al., 2015; Ovando \& Cavazos, \\
& 2004; Öztürk, 2012; Powell \& McGowan, \\
& 1996; Pugh \& Zhao, 2003) \\
\hline Professional development & (Friedman, 1999; Powell \& McGowan, 1996; \\
& Webb, 2002; Wilson, 1993) \\
\hline
\end{tabular}




\section{Table 2}

Items of the Teacher Autonomous Behaviour Scale. Items are based upon Kwakman (2003) and Pearson and Moomaw (2005, 2006). Items with an asterisk are deleted from the final scale after exploratory and confirmatory factor analyses.

\begin{tabular}{|c|c|}
\hline Dimensions & Items \\
\hline \multirow[t]{7}{*}{ Primary work processes in the class } & I have a say in the planning of my work activities. \\
\hline & I have influence on my pace of work. \\
\hline & $\begin{array}{l}\text { I have a say in the (educational) tasks that are assigned } \\
\text { to me. } \\
\text { I am free to be creative in my teaching approach. }\end{array}$ \\
\hline & $\begin{array}{l}\text { The selection of student-learning activities in my class is } \\
\text { under my control.* }\end{array}$ \\
\hline & My job allows for much discretion on my part. \\
\hline & $\begin{array}{l}\text { I have a say over the scheduling of use of time in my } \\
\text { lessons. }\end{array}$ \\
\hline & $\begin{array}{l}\text { I select the teaching methods and strategies I use with } \\
\text { my pupils/students.* }\end{array}$ \\
\hline \multirow[t]{6}{*}{ Curriculum implementation } & In my teaching, I use my own guidelines and procedures. \\
\hline & $\begin{array}{l}\text { In my situation, I have much to say over the educational } \\
\text { content (knowledge and skills) that I am supposed to } \\
\text { teach. }\end{array}$ \\
\hline & $\begin{array}{l}\text { My teaching approach focuses on those goals I select } \\
\text { myself. }\end{array}$ \\
\hline & $\begin{array}{l}\text { What I teach in my lessons is determined for the most } \\
\text { part by myself. }\end{array}$ \\
\hline & $\begin{array}{l}\text { The materials I use in my lessons are chosen for the } \\
\text { most part by me. }\end{array}$ \\
\hline & $\begin{array}{l}\text { The educational content (knowledge and skills) taught in } \\
\text { my lessons are those I select. }\end{array}$ \\
\hline \multirow{5}{*}{$\begin{array}{l}\text { Participation in decision making at } \\
\text { school }\end{array}$} & I determine what happens at my workplace. \\
\hline & I co-decide about things that are related to my work. \\
\hline & $\begin{array}{l}\text { I have a say in what does and does not belong to my } \\
\text { task.* }\end{array}$ \\
\hline & I co-decide about the nature of my work activities. \\
\hline & I have a direct say in decisions of the school. \\
\hline \multirow[t]{6}{*}{ Professional development } & $\begin{array}{l}\text { I have a say in the planning of my professional } \\
\text { development activities.* }\end{array}$ \\
\hline & $\begin{array}{l}\text { I have influence on the pace of my professional } \\
\text { development activities. }\end{array}$ \\
\hline & I have a say in which professional development activities \\
\hline & I perform \\
\hline & $\begin{array}{l}\text { I co-decide about the moment on which my professional } \\
\text { development activities need to be finished. }\end{array}$ \\
\hline & $\begin{array}{l}\text { I have a say in how much time I spend on a certain } \\
\text { professional development activity. }\end{array}$ \\
\hline
\end{tabular}




\section{Table 3.}

Fit values of all four factor models

\begin{tabular}{llllllrr} 
Model & $\mathrm{df}$ & $\chi^{2}$ & CFI & TLI & RMSEA & $\Delta \chi^{2}$ & $\Delta \mathrm{df}$ \\
\hline 1 Factor & 170 & 5573 & .648 & .606 & .169 & & \\
2 Factors & 169 & 3740 & .768 & .732 & .130 & 1833 & 1 \\
3 Factors & 167 & 2795 & .829 & .797 & .112 & 945 & 2 \\
4 Factors & 164 & 1268 & .928 & .917 & .078 & 1527 & 3 \\
\hline
\end{tabular}


Table 4.

Reliabilities of the four dimensions

Scale

Cronbach's alpha

Teacher autonomous behaviour

Primary work processes in the class

.87

Curriculum implementation

.89

Participation in decision making at school

.86

Professional development

.94 


\section{Table 5}

Cross-validation for primary, secondary, and vocational education

\begin{tabular}{llllll} 
Group & $\mathrm{N}$ & $\chi^{2}$ & $\mathrm{CFI}$ & $\mathrm{TLI}$ & RMSEA \\
\hline $\begin{array}{l}\text { 1 primary } \\
\text { education }\end{array}$ & 493 & 714 & .922 & .910 & .083 \\
$\begin{array}{l}\text { 2 secondary } \\
\text { education }\end{array}$ & 392 & 622 & .913 & .899 & .086 \\
$\begin{array}{l}\text { 3 vocational } \\
\text { education }\end{array}$ & 207 & 377 & .926 & .914 & .079 \\
\hline
\end{tabular}


Table 6

Descriptives and correlations between variables. Cronbach's alpha on diagonal

\begin{tabular}{|c|c|c|c|c|c|c|c|c|c|c|c|c|}
\hline & Mean & SD & 1 & 2 & 3 & 4 & 5 & 6 & 7 & 8 & 9 & 10 \\
\hline 1.PD Experimenting & 4.02 & 1.18 & .86 & & & & & & & & & \\
\hline 2. PD Reflecting & 4.43 & 1.16 & .51 & .76 & & & & & & & & \\
\hline 3. PD Col. school devel. & 4.83 & 1.31 & .39 & .36 & .85 & & & & & & & \\
\hline 4. TA Primary work process & 5.02 & 1.20 & .22 & .25 & .16 & .87 & & & & & & \\
\hline 5. TA Curriculum impl. & 4.37 & 1.24 & .30 & .28 & .16 & .73 & .89 & & & & & \\
\hline 6. TA Participation & 4.55 & 1.25 & .28 & .23 & .41 & .52 & .54 & .86 & & & & \\
\hline 7. TA Prof. development & 4.53 & 1.37 & .23 & .21 & .26 & .43 & .42 & .63 & .94 & & & \\
\hline 8. Perceived autonomy & 4.89 & 1.14 & .26 & .26 & .27 & .52 & .45 & .57 & .53 & .89 & & \\
\hline 9. Bureaucracy & 4.40 & 1.50 & .10 & .00 & .10 & -.24 & -.10 & -.20 & -.26 & -.31 & .90 & \\
\hline 10. Transform. leadership & 4.27 & 1.39 & .24 & .17 & .34 & .20 & .20 & .42 & .39 & .41 & -.16 & .95 \\
\hline
\end{tabular}




\section{Table 7}

Convergent validity of teacher autonomous behaviour subscales

Teacher autonomous behaviour subscale

PA

Primary work process $\quad .523$

Curriculum implementation $\quad .445$

Participation $\quad .570$

Professional Development $\quad .526$ 


\section{Table 8}

Discriminant validity of teacher autonomous behaviour subscales

Teacher autonomous behaviour subscale BC

Primary work process $\quad-.238$

Curriculum implementation $\quad-.099$

Participation $\quad-.204$

Professional Development $\quad-.257$ 


\section{Table 9}

Correlations with three sub scales of PD

Professional

Development

\begin{tabular}{rrrr}
\hline $\begin{array}{r}\text { Teacher autonomous } \\
\text { behaviour } \\
\text { subscale }\end{array}$ & Experimenting & Reflecting & $\begin{array}{r}\text { Collaborating } \\
\text { school- } \\
\text { development }\end{array}$ \\
Primary work process & .224 & .254 & .159 \\
Curriculum implementation & .296 & .284 & .161 \\
Participation & .277 & .229 & .405 \\
Professional Development & .225 & .213 & .264 \\
\hline
\end{tabular}




\section{Table 10}

Transformational leadership predicting Teacher autonomous behaviour

\begin{tabular}{|c|c|c|c|c|c|c|c|c|}
\hline \multirow{3}{*}{$\begin{array}{l}\text { Dependent } \\
\text { Variable }\end{array}$} & \multirow[b]{3}{*}{ Parameter } & \multirow[b]{3}{*}{ B } & \multirow{2}{*}{\multicolumn{2}{|c|}{ Std. }} & \multirow[b]{3}{*}{ Sig. } & \multicolumn{2}{|c|}{ 95\% Confidence Interval } & \multirow{3}{*}{$\begin{array}{c}\text { Partial Eta } \\
\text { Squared }\end{array}$} \\
\hline & & & & & & Lower & Upper & \\
\hline & & & Error & $\mathrm{t}$ & & Bound & Bound & \\
\hline \multirow{2}{*}{$\begin{array}{l}\text { TA Primary } \\
\text { work process }\end{array}$} & Intercept & 4.165 & .102 & 40.713 & .000 & 3.965 & 4.366 & .599 \\
\hline & $T L$ & .240 & .023 & 10.554 & .000 & .196 & .285 & .091 \\
\hline \multirow{2}{*}{$\begin{array}{l}\text { TA Curriculum } \\
\text { implementation }\end{array}$} & Intercept & 3.614 & .119 & 30.426 & .000 & 3.381 & 3.847 & .455 \\
\hline & $\mathrm{TL}$ & .178 & .026 & 6.747 & .000 & .127 & .230 & .039 \\
\hline \multirow[t]{2}{*}{ TA Participation } & Intercept & 2.927 & .110 & 26.509 & .000 & 2.711 & 3.144 & .388 \\
\hline & TL & .381 & .025 & 15.500 & .000 & .333 & .429 & .178 \\
\hline \multirow{2}{*}{$\begin{array}{l}\text { TA Professional } \\
\text { development }\end{array}$} & Intercept & 2.875 & .122 & 23.499 & .000 & 2.635 & 3.115 & .332 \\
\hline & $\mathrm{TL}$ & .388 & .027 & 14.249 & .000 & .335 & .442 & .155 \\
\hline
\end{tabular}

